\title{
MONTAGNEA HAUSSKNECHTII RAB. (PODAXALES) A RARE AGARICOID FUNGUS: FIRST RECORD FROM BRAZIL ${ }^{1}$
}

\author{
Iuri Goulart Baseia ${ }^{24}$
}

Adauto Ivo Milanez ${ }^{3}$

Recebido em 14/08/2001. Aceito em 15/01/2002.

\begin{abstract}
RESUMO - (Montagnea haussknechtii Rab. (Podaxales) um raro fungo agaricóide: primeira citação para o Brasil). Esta espécie xerófila é registrada pela primeira vez para o Brasil, encontrada em solo arenoso de cerrado do Estado de São Paulo. São fornecidas descrições das características macro e microscópicas a partir de basidiocarpos maduros e adicionalmente, microscopia eletrônica de varredura dos esporos.
\end{abstract}

Palavras-chave - Taxonomia, foto-MEV, cerrado, estado de São Paulo

ABSTRACT- (Montagnea haussknechtii Rab. (Podaxales) a rare agaricoid fungus: first record from Brazil). This xerophilic species is recorded for the first time from Brazil, found on sandy soil from cerrado of the State of São Paulo. A description of the macro and microscopic features from mature basidiomata is given. Pictures of the spores under the scanning electron microscope are added.

Key words - Taxonomy, SEM-picture, cerrado, São Paulo state

\section{Introduction}

The genus Montagnea was established by E. M. Fries (1836) in honor to the French mycologist C. Montagne, who had initially sent the dried material, which served as the basis for the generic description. This genus is mainly characterized by its agaricoid appearance with the apex of the stipe expanded into a disc from the margin of which hang the radiating, lamelloid, black, naked tramal plates.

According to Hawksworth et al. (1995), Podaxales is an improper order of Gasteromycetes; on the other hand, Dring (1973) includes Podaxaceae belonging to Agaricales. However, various authors like as Liu (1984), Dörfelt \& Bum•aa (1986), Chio et al. (1990), Reid \& Eicker (1991) and Pardavé (1991), yet consider this group as belonging to the

${ }^{1}$ Parte da Tese de Doutorado do primeiro autor. Bolsista CAPES.

${ }^{2}$ Aluno de Doutorado do Instituto de Biociências/USP, ibaseia@bol.com.br

${ }^{3}$ Instituto de Botânica, C. Postal 4005, 01061-970, São Paulo, SP, Brasil.

${ }^{4}$ Depto. de Micologia - CCB, Universidade Federal de Pernambuco, Cidade Universitária, 50.670-901, Recife, PE. 
Gasteromycetes. Hence, we note some controversy about the mentioned statements by Dring (1973) and Hawksworth et al. (1995). Currently, four taxa are recognized for the genus, Montagnea arenaria (DC.) Zeller, M. arenaria var. macrospora Reid \& Eicker, M. schuppii Rick and M. haussknechtii Rab. These species are separated mainly on the basidiomata and basidiospores sizes.

There are not enough studies about this genus from South America; few specimens in the herbaria were not even studied. This work highlights some results for a survey of gasteroid fungi from the cerrado areas in the State of São Paulo. The aim here is to get an improved insight on this polyphiletic group, by including a detailed description of micro and macroscopic features from mature basidiomata.

\section{Material and methods}

Fieldworks have been made in the "Estação Ecológica de Jataí", located in the State of São Paulo. This area is characterized by seasonal but moderately deciduous forest, occurring in the high-altitude (520-851 m), also appearing on soils of intermediate fertility. Climatic conditions are of the AW type according to Köppen System.

Fresh and dried material were prepared for examination under light microscope by removing small sections of the hymenium, and soaking them in Melzer's reagent plus 5\% $\mathrm{KOH}$ (Singer, 1986). Color terms in parenthesis are those of Kornerup \& Wanscher (1978). The material is preserved at the Herbario do Estado Maria Eneyda P. K. Fidalgo (SP).

Spores have been examined in a Philips XL 20 scanning electron microscope. The investigated matter has been mounted dusting it over aluminum stubs and covered with a thin layer of gold-palladium in Sputter Coater BalTec SCD-050.

\section{Results and discussion}

Montagnea haussknechtii Rab., Sitzungsber, naturw. Ges. 'Isis' Dresden 8, 1870.

Synonyms: Montagnites elliottii Mass., Grevillea 21, 1, 1892; Montagnites tenuis Pat., Jl. Bot. 8, 219, 1894; Montagnea tenuis (Pat.) Teng. Fungi of China 762, 1964; Montagnites candollei var. minor P. Henn., Hedwigia 40(98), 1901; Montagnites candollei var. coprinoides P. Henn., Hedwigia 40(98), 1901; Montagnites candollei var. somala Bacc., Eumycet. Somalia 191, 1916; Montagnites spegazzini Sacc. \& Trott., Syll. Fung. 23, 327, 1925 (Reid \& Eicker 1991).

Fig. 1

Basidiomata agaric-like 6-7 cm. high. Pileus 3-4 cm diam., conic-truncate, depressed in the center, yellowish brown (5F4) to brownish grey (5F2). Stipe woody, yellowish brown (5F4), cylindrical, 7-8 cm. tall., covered with some coarse lacerated scales, longitudinally wrinkled and at the base an inconspicuous fringed papery volva. Lamellae numerous, black to dark grey (3F3), very crowded, radially orientated. Hymenium comprising of 4-spored basidia. Spore powder dark grey (3F3), basidiospores 6-7 x 3-4 mm, elliptic to pyriform, with a slightly thickened wall, and a germ pore, sessile, dark brown.

Material examined: BRAZIL, São Paulo: Município de Luís Antônio, Estação Ecológica de Jataí, 09/V/2000, I. G. Baseia (SP 307517); 23/III/2001, I. G. Baseia (SP 307552).

Habitat: Solitary on sandy soil in open sunlight of cerrado region.

Distribution: Russia (Sorokin, 1884); Egypt (Massee, 1892); Africa (Hennings, 1901); United States of America (Zeller, 1943); Iran (Petrak, 1949); Canary Islands (Eckblad, 1962; 1975); Israel (Dring \& Rayss, 1963); Afghanistan (Eckblad, 1970); Cuba (Kreisel, 1971); Spain (Calonge, 1975) Turkey (Watling \& Gregory, 1977); China (Liu, 1984). 

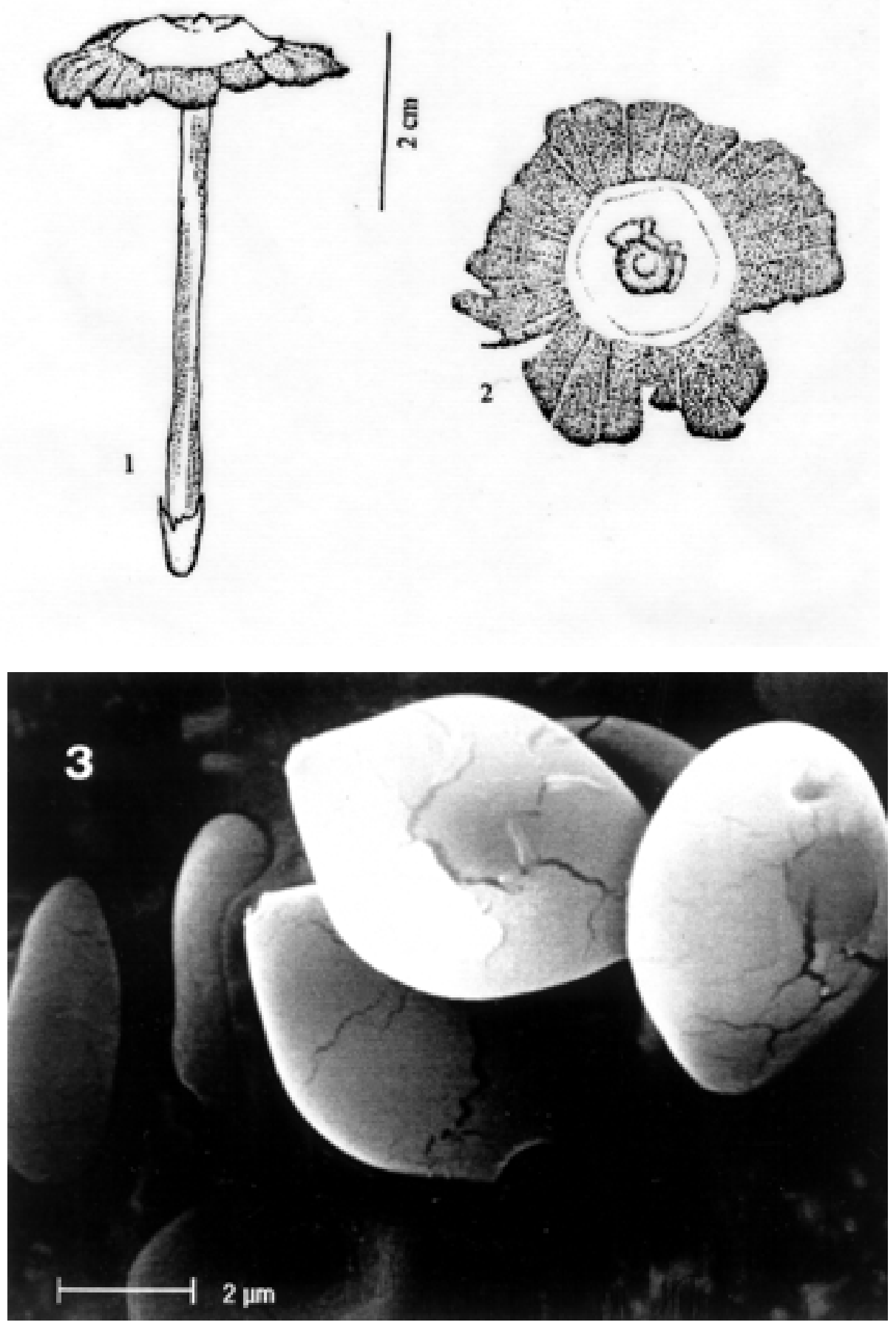

Figs. 1-3. Montagnea haussknechtii: 1. mature basidioma; 2. higher surface of pileus; 3. basidiospores under SEM 
Discussion: Montagnea Fr. has been made the type genus of the Montagneaceae Sing. (Singer 1976) that comprises two other genera: Panaeolopsis Sing. and Polyplocium Berk. However, Singer (1986) observed that the affinities of his new family Montagneaceae lie with Coprinaceae in the Agaricales. On that occasion, Singer (1986) wrote about Montagnea: "Many authors consider this genus as belonging to the Agaricales, somewhere near Coprinus. There is no doubt in the author's mind but that Montagnea is, indirectly, related with the Coprinaceae. However, if there is such a thing as a Gasteromycete, Montagnea is one of them". There are evidences from rDNA sequences data to support long-held hypothesis for other close relationship among secotioid, falsetruffle and agaric forms (Vilgalys et al. 1993). The examples include the shaggy mane mushroom, Coprinus comatus and the gasteroid forms Montagnea and Podaxis.

Montagnea and the genus Gyrophragmium share superficial resemblance, such as: size, color and texture of the gills and the presence of a small volva at the base of the stipe; but they differ mainly by the gills that are lamellate and radiate in Montagnea while in Gyrophragmium the tramal plates are separated and arranged in parallel lines.

From Brazil, there was only one record for this genus: M. schuppii, given by Rick (1928; 1939). M. haussknechtii and M. schuppii differ mainly by the size and color of the pileus that in M. schuppii are bigger and clear. This is the first record of Montagnea haussknechtii from Brazil.

\section{Acknowledgments}

We thank the financial support of the Coodernação de Aperfeiçoamento de Pessoal de Nível Superior (CAPES), the Instituto de Biociências/USP and Seção de Micologia e Liquenologia/IBt . We also thank the referee's suggestions for improving the paper.

\section{References}

Calonge F. D. 1975. Ornamentación de las esporas de algunos Gasteromycetes Españoles. Anales des Instituto Botânico Antonio Jose Cavanilles 32: 103-115.

Chio R. E., Guzmán G. \& Bandala V. M. 1990. Fungi from the State of Mexico, III. Species reported in the bibliography: Gasteromycetes. Revista Mexicana de Micologia 6: 207-220.

Dörfelt H. \& Bum•aa, D. 1986. Die Gasteromyceten (Bauchpilze) der Mongolischen Volksrepublik. Nova Hedwigia 43: 87-111.

Dring, D. M. 1973. Gasteromycetes. In: Ainsworth, G. C., Sparrow, F. K. \& Sussman, A. S. The Fungi - an advanced treatise, p. 451-478.

Dring D. M. \& Rayss T. 1963. The Gasteromycete fungi of Israel. Israel Journal of Botany 12: 147-178.

Eckblad F. E. 1962. Gasteromycetes from the Canary Islands. Nytt Magasin for Botanikk 9: 135-138.

Eckblad F. E. 1970. Gasteromycetes from Iraq, Iran and Afghanistan. Norwegian Journal of Botany 17: 129-138.

Eckblad F. E. 1975. Additions and corrections to the Gasteromycetes of the Canary Islands. Norwegian Journal of Botany 22: 243-248.

Fries E. M. 1836. Genera Hymenomycetum. Upsaliae. Excudebant Regiae Acad. Typography.

Hawksworth, D. L., Kirk, P. M.; Sutton, B. C. \& Pegler, D. N. 1995. Ainsworth \& Bisby's Dictionary of the fungi. Surrey, 8 th edn., International Mycological Institute, $412 \mathrm{pp}$.

Hennings, P. 1901. Aliquot Fungi Africae borealis a cl. Dr. G. Schweinfurth collecti. Hedwigia 40: 98-101.

Kornerup A. \& Wanscher J. E. 1978. Methuen Handbook of Colour, 3th edn., London, Methuen, 243 p.

Kreisel H. 1971. Charakteristika der Pilzflora Kubas. Biologische Rundschau 65: 72 .

Liu B. 1984. The Gasteromycetes of China. Beihefte zur Nova Hedwigia 74: 1-235.

Massee, G. 1892. Notes on exotic fungi in the Royal Herbarium, Kew. Grevillea 21: 1-6.

Morse E. E. 1948. Variation in Montagnites arenarius (DC.). Mycologia 40: 255-261.

Pardavé L. M. 1991. Gasteromycetes of the State of Aguascalientes. Revista Mexicana de Micologia 7: 71-78.

Petrak F. 1949. Beiträge zur Pilzflora Irans. Sydovia 3: 268-332.

Reid D. A. \& Eicker A. 1991. A taxonomic survey of the genus Montagnea (Gasteromycetes) with special reference to South Africa. South African 
Journal of Botany 57(3): 161-170.

Rick J. 1928. Montagnites schuppii Rick. Egatea 13: 434. Rick J. 1939. Agarici Riograndenses IV. Lilloa 4: 75-104. Singer R. 1976. Amparionaceae and Montagneaceae.

Revue de Mycologie 40: 59-64.

Singer R. 1986. The Agaricales in Modern Taxonomy. 4th edn. Koeltz Scientific Books, Koenigstein.

Sorokin, N. W. 1884. Materialy dlja Flory sred nej Asii.

Bulletin de La Societe Imperiale des Naturalists de Moscou 59: 183-230.

Spegazzini C. 1912. Mycetes Argentinenses Series 6. Anales del Museo Nacional de Buenos Aires 23: 1-146.

Vilgalys R., Hopple J. \& Hibbett D. S. 1993. Phylogenetic Implications of Genetic Concepts in Fungal Taxonomy: The Impact of Molecular Systematic Studies. Mycology Helvetica 6: 73-91.

Watling R. \& Gregory N. M. 1977. Larger Fungi from Turkey, Iran and neighbouring countries. Karstenia 17: 59-72.

Zeller S. M. 1943. North American species of Galeropsis, Gyrophragmium, Longia and Montagnea. Mycologia 35: 409-421. 
Baseia, I. G. \& Milanez, A. I. 